\title{
Influence of food restriction on the reproduction and larval performance of matrinxã, Brycon amazonicus (Spix and Agassiz, 1829)
}

\author{
Camargo, ACS. a and Urbinati, EC. ${ }^{\mathrm{b} *}$ \\ ${ }^{a}$ Núcleo de Ciência Agrárias, Universidade Federal de Minas Gerais - UFMG, \\ Av. Osmani Barbosa, Bairro JK, CEP 39404-006, Montes Claros, MG, Brazil \\ bDepartamento de Morfologia e Fisiologia Animal, Faculdade de Ciências Agrárias e Veterinárias, \\ Centro de Aqüicultura, Universidade Estadual Paulista - UNESP, \\ Via de Acesso Prof. Paulo Donato Castelane, CEP 14884-900, Jaboticabal, SP, Brazil \\ *email: bethurb@caunesp.unesp.br \\ Received March 4, 2007 - Accepted June 1, 2007 - Distributed November 30, 2008
}

(With 4 figures)

\begin{abstract}
This work evaluated the effect of food restriction and refeeding of matrinxã females, Brycon amazonicus, on their reproductive performance and on the growth and survival of the progeny. Broodstocks were distributed in 8 earthen tanks (15 fish/tank) and fish from 4 tanks were fed daily (G1) while fish from the other 4 tanks were fed for 3 days and not fed for 2 days (G2) during 6 months prior to artificial spawning. Among the induced females, $57 \%$ in G1 group and $45 \%$ in G2 group spawned and the mean egg weights were $208.1 \mathrm{~g}(\mathrm{G} 1)$ and $131.6 \mathrm{~g}(\mathrm{G} 2)$. Oocytes of G2 fish were smaller (1.017 \pm $0.003 \mathrm{~mm})$ than oocytes of G1 fish $(1.048 \pm 0.002 \mathrm{~mm})$. Fertilization $(71.91 \pm 12.6 \%$ and $61.18 \pm 13.7 \%)$ and hatching $(61.28 \pm 33.9 \%$ and $67.50 \pm 23.4 \%)$ rates did not differ between G1 and G2 fish. Larvae were collected at hatching and at 24,48 and 72 hours of incubation and fixed for growth measurement. After incubation, fry were transferred to aquaria and sampled 1, 5, 9 and 15 days later. G1 and G2 larvae had similar weight ( $1.51 \pm 0.15$ and $1.46 \pm 0.07 \mathrm{mg})$ but the G2 length was significantly higher $(6.26 \pm 0.13$ and $6.74 \pm 0.14 \mathrm{~mm})$. By the ninth day of rearing, G2 fry had higher weight (13.6 \pm 0.26 and $18.9 \pm 0.07 \mathrm{mg}$ ) and length $(11.8 \pm 0.09$ and $14.5 \pm 0.04 \mathrm{~mm})$ but by the fifteenth day, G1 fry had higher weight $(90.2 \pm 1.19$ and $68.6 \pm 0.77 \mathrm{mg})$ and length $(18.8 \pm 0.16$ and $18.5 \pm 0.04 \mathrm{~mm})$ than $\mathrm{G} 2$ fry. By the ninth day of rearing, when fry are recommended to be transferred to outdoor tanks, G2 fry were larger and after 15 days, fry produced by restricted-fed females showed higher survival. The survival rate of G2 progeny by the fifteenth day was significantly higher $(24.7 \pm 2.07 \%)$ than that of G1 progeny $(19.2 \pm 1.91 \%)$. The ration restriction ( $35 \%$ reduction) imposed on matrinxã broodstock during 6 months prior to spawning reduced the number of spawned females and the egg amount, but it did not affect fertilization and hatching rates. Otherwise restricted-female larvae were larger and presented higher survival.
\end{abstract}

Keywords: feeding restriction, reproductive performance, larval performance.

\section{Influência da restrição alimentar no desempenho reprodutivo e larval do matrinxã, Brycon amazonicus (Spix e Agassiz, 1829)}

\begin{abstract}
Resumo
Este estudo avaliou o efeito da restrição alimentar e realimentação na reprodução de fêmeas e no crescimento inicial e sobrevivência de larvas de matrinxã, Brycon amazonicus. Matrizes distribuídas em 8 viveiros (15 peixes/tanque) foram alimentadas diariamente (em 4 tanques - G1) e alimentados em ciclos de 3 dias de alimentação seguidos de 2 dias de restrição (em 4 tanques - G2) por 6 meses antes da desova. Na indução à desova, 57\% das fêmeas no G1 e 45\% no G2 desovaram. Os pesos médios dos oócitos foram 208,1 g (G1) e 131,6 g (G2), sendo os oócitos G2 menores (1,017 \pm $0,003 \mathrm{~mm})$ que os oócitos de G1 $(1,048 \pm 0,002 \mathrm{~mm})$. As taxas de fertilização $(71,9 \pm 12,6 \%$ e $61,2 \pm 13,7 \%)$ e de eclosão (61,3 $\pm 33,9 \%$ e $67,5 \pm 23,4 \%)$ entre os G1 e G2 não diferiram. Larvas foram coletadas na eclosão e às 24,48 e 72 horas de incubação para medida do crescimento e as restantes transferidas para aquários e amostradas $1,5,9$ e 15 dias depois. Na transferência, as larvas G1 e G2 tinham pesos similares (1,5 $\pm 0,15$ e 1,46 $\pm 0,07 \mathrm{mg})$, mas o comprimento das larvas $\mathrm{G} 2$ era maior $(6,2 \pm 0,13$ e $6,7 \pm 0,14 \mathrm{~mm})$. Ao $9^{\circ}$ dia, quando é recomendada a transferência dos juvenis para tanques externos, os juvenis $\mathrm{G} 2$ tinham peso $(13,6 \pm 0,26$ e $18,9 \pm 0,07 \mathrm{mg})$ e comprimento $(11,8 \pm 0,09 \mathrm{e}$ $14,5 \pm 0,04 \mathrm{~mm})$ maiores, mas no $15^{\circ}$ dia os juvenis G1 eram maiores em peso $(90,2 \pm 1,19$ e $68,6 \pm 0,77 \mathrm{mg})$ e comprimento $(18,8 \pm 0,16$ e 18,5 $\pm 0,04 \mathrm{~mm})$. Aos 15 dias, a prole das fêmeas submetidas à restrição alimentar apresentou sobrevivência mais alta que a prole das fêmeas alimentadas diariamente $(24,7 \pm 2,07 \%$ e $19,2 \pm 1,91 \%)$. A restrição alimentar imposta às fêmeas de matrinxã, apesar de reduzir o número de fêmeas que desovaram e a quantidade de oócitos extrusados, não afetou a fertilização e eclosão das larvas e melhorou a sobrevivência final das larvas.
\end{abstract}

Palavras-chave: restrição alimentar, desempenho reprodutivo, desempenho larval. 


\section{Introduction}

An improvement in broodstock nutrition and feeding has shown to improve not only the reproductive performance of breeders but also the quality of gametes and fry production while food restriction can affect spawning success (Izquierdo et al., 2001). However, reduction in food intake is a natural occurrence during the life cycle of fish including the spawning migration (Mackenzie et al., 1998). In captivity, fish are fed daily even when the food intake decreases naturally. The understanding of the effect of food restriction and refeeding in broodstock management could be useful to minimize costs in aquaculture. The reduced feeding rate effects on the reproductive performance of fish are still controversial. Food restriction did not affect testis development of Cichlasoma nigrofasciatum Günther, 1867 (Townshend and Wooton, 1984), gonadosomatic index (GSI) and egg quality of rainbow trout (Ridelman et al., 1984), number of mature males of Salvelinus alpinus Linnaeus, 1758 (Jobling et al., 1993) and no alteration was observed in GSI of Tilapia zillii Gervais, 1848 (Coward and Bromage, 1999). However, reduction in feeding rate has shown to inhibit gonadal maturation in salmonids (Thorpe et al. 1990; Reimers et al., 1993; Hopkins and Unwin, 1997), Dicentrarchus labrax Linnaeus, 1758 (Cerdá et al. 1994), and maturation of Scophthalmus maximus Linnaeus, 1758 females, but not males (Bromley et al., 2000). Females are believed to be more responsive to food restriction (Karlsen et al., 1995; Silverstein and Shimma, 1994; Duston and Saunders, 1999). On the other hand, feeding ratio reduction (cycles of 3 days fed/2 days unfed imposed throughout one year) did not affect gonadal development and plasma testosterone levels of Brycon amazonicus Spix and Agassiz, 1829 male and female (Carvalho, 2001).

Morphological, physiological and biochemical characteristics of the resulting progeny are directly or indirectly related to the nutritional status of the broodfish during some time before the reproductive process takes place (Carrillo et al., 2000). Teleost are endowed with the ability to sense nutritional state and regulate their reproductive development and activity accordingly. However it is not yet clear how ration restriction can affect the egg quality and progeny performance. After 6 months of feeding Dicentrarchus labrax broodstock at a half feed ration, eggs and newly hatched larvae were smaller than those obtained from fish fed full rations (Cerdá et al., 1994).

The enhancement of the farming of many species in Brazil is still ongoing, especially concerning management of broodfish. Among the economically important farmed species, matrinxã (Brycon amazonicus) has deserved attention as a food and sport fish. This study evaluated the effects of cycles of food restriction and refeeding during 6 months prior to spawning, on the reproductive performance of matrinxã females and on the growth and survival of the progeny.

\section{Material and Methods}

A total of 120 fish, females and males (mean body weight $1.65 \mathrm{~kg}$ ), were distributed in 8 earthen tanks $\left(40 \mathrm{~m}^{2}\right)$ with running water flow. Feeding intake was registered for 15 days to determine the feeding rate. Fish were randomly separated in 2 groups: fed daily - G1 and fed/unfed - G2 (4 tanks/treatment, 15 fish/tank). G1 fish were fed daily (2\% biomass) and G2 fish were fed 3 days and refrained from feeding 2 days, then fed again and so on, during 6 months prior to spawning (April to October). When fed, G2 fish received the same amount of feed as G1 fish. Fish were fed with a commercial diet ( $28 \%$ crude protein) once a day, in the afternoon. Water temperature in the tanks was monitored daily.

\subsection{Hormonal induction to spawning}

At spawning, G1 $(n=28)$ and G2 $(n=37)$ females were selected for hormonal induction with carp pituitary extract. Females received $5.5 \mathrm{mg} . \mathrm{kg}^{-1}$ b.w. in 2 applications (primer dose of $0.5 \mathrm{mg} \cdot \mathrm{kg}^{-1}$, and final dose of $5 \mathrm{mg} \cdot \mathrm{kg}^{-1}$ after 10 hours) and males received a single injection of $2.0 \mathrm{mg} \cdot \mathrm{kg}^{-1}$ at the time of the second injection in the females. Only pooled milt from males $(n=4)$ of the G1 group was used to isolate the effect of food restriction.

\subsection{Rearing larvae and fry}

After extrusion, a sample of oocytes was fixed for diameter measurement. Eggs from 8 females (4 G1 and 4 G2) were fertilized with pooled milt and were kept in individual $100 \mathrm{~L}$ incubators ( 1 for each female, $100 \mathrm{~g}$ eggs per incubator) with controlled water flow. They were collected 6 and 12 hours after fertilization for determination of fertilization and hatching rates. Larvae were fixed at hatching and after 24, 48 and 72 hours for growth measurements. After 72 hours incubation, 4,000 G1 larvae and 4,000 G2 larvae were transferred to $25 \mathrm{~L}$ aquaria at a stocking density of 10 larvae/L, with 16 aquaria/treatment, 4 replicates/female). At 1, 5, 9 and 15 days of rearing, 10 larvae from each aquarium were sacrificed in iced water and fixed for weight and length measurements. At 15 days, remaining fry were sampled for size measurements and survival calculations. Water $\mathrm{pH}$ (Meter model 63 YSI), temperature and dissolved oxygen (Meter model 55 YSI) were monitored every other day in all aquaria. Mean water temperature in broodstock tanks was $24.7 \pm$ $0.2{ }^{\circ} \mathrm{C}$, in incubators $25.7 \pm 0.7^{\circ} \mathrm{C}$ and in aquaria $24.6 \pm$ $0.2{ }^{\circ} \mathrm{C}$. Water $\mathrm{pH}$ and dissolved oxygen concentration in aquaria were $8.27 \pm 0.14$ and $6.33 \pm 1.17 \mathrm{mg} . \mathrm{L}^{-1}$, respectively. The parameter values were within the ranges considered appropriate for tropical fish culture (Boyd, 1979).

\subsection{Statistical analysis}

Data of weight and length were analyzed using a factorial scheme (factors: treatments - fed daily and food restriction, and sampling times) in a completely randomized design (CRD) by a two-way analysis of variance Data of oocyte diameter, fertilization and hatching rates 
and survival were analyzed by a one way analysis of variance. Data of fertilization and hatching rates were submitted to angular transformation $\mathrm{y}=\operatorname{arcsen} . \sqrt{\mathrm{x} / 100}$ to minimize the coefficient of variation. Means were compared by the Tukey test $(\mathrm{p}<0.05)$. Analyses were made using the SAS software.

\section{Results}

From 28 G1 females hormonally induced, only 16 spawned (57\%), and from 37 G2 females only 17 spawned (45\%). G1 females produced on average $208.08 \mathrm{~g}$ of eggs and G2, $131.56 \mathrm{~g}$. The mean oocyte diameter of G2 females was significantly smaller than that of G1 females $(1.017 \pm 0.003 \mu \mathrm{m}$ and $1.048 \pm 0.002 \mu \mathrm{m}$, respectively, Figure 1). The fertilization and hatching rates were not affected by food restriction as shown in Figure 1 $(71.91 \pm 12.66 \%$ and $61.18 \pm 13.75 \% ; 61.28 \pm 33.96 \%$ and $67.50 \pm 23.38 \%$, for $\mathrm{G} 1$ and $\mathrm{G} 2$, respectively).

Weight and length of G1 and G2 larvae after 72 hours incubation are presented in Figure 2. At hatching, weight and length of G1 and G2 did not differ $(0.64 \pm 0.07 \mathrm{mg}$ and $0.64 \pm 0.01 \mathrm{mg} ; 2.66 \pm 0.34 \mathrm{~mm}$ and $2.63 \pm 0.02 \mathrm{~mm}$, respectively). The same was observed at 24 hours $(0.78 \pm$ $0.05 \mathrm{mg}$ and $0.76 \pm 0.01 \mathrm{mg} ; 4.51 \pm 0.27 \mathrm{~mm}$ and $4.70 \pm$ $0.04 \mathrm{~mm}$, respectively). At 48 hours, G1 weight was significantly higher $(1.36 \pm 0.15$ and $1.07 \pm 0.07 \mathrm{mg})$, and length did not differ $(5.58 \pm 0.36$ and $5.97 \pm 0.46 \mathrm{~mm}$, respectively). At the last sampling in the incubators (72 hours), weights were similar and G2 larvae had higher length $(1.51 \pm 0.15 \mathrm{mg}$ and $1.46 \pm 0.01 \mathrm{mg} ; 6.26 \pm$ $0.13 \mathrm{~mm}$ and $6.74 \pm 0.14 \mathrm{~mm}$ ).

The weights and lengths of G1 and G2 fry after 15 days of rearing are presented in Figure 3. At 9 days of rearing G2 group were larger and heavier than G1 group $(18.9 \pm 0.07 \mathrm{mg}$ and $13.6 \pm 0.26 \mathrm{mg} ; 14.5 \pm 0.04 \mathrm{~mm}$ and $11.8 \pm 0.09 \mathrm{~mm}$ ) but at the end of rearing, G1 fry became larger $(90.2 \pm 1.19 \mathrm{mg}$ and $68.6 \pm 0.77 \mathrm{mg}$;

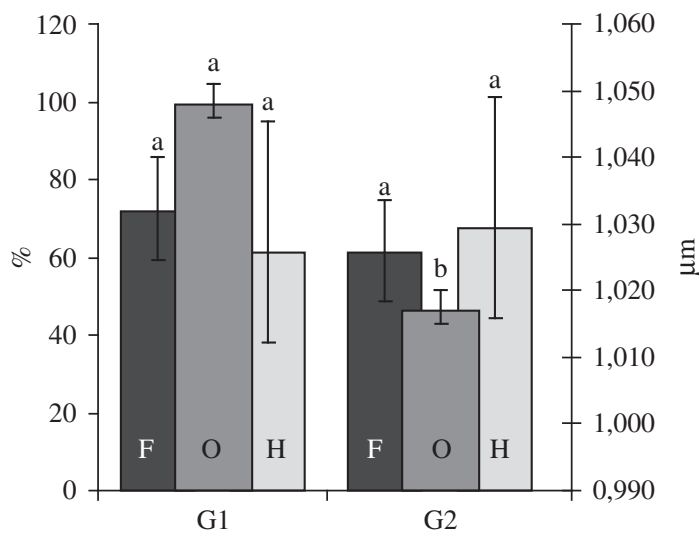

Figure 1. Fertilization (F) (\%), hatching $(\mathrm{H})(\%)$ and oocyte diameter $(\mathrm{O})(\mathrm{mm})$ of matrinxã females fed daily $(\mathrm{G} 1)$ and those fed 3 days/unfed 2 days (G2). Same letters indicate no significant differences between treatments.
$18.8 \pm 0.16 \mathrm{~mm}$ and $18.5 \pm 0.04)$. At 15 days the survival of $\mathrm{G} 2$ progeny was higher than that of the G1 progeny (19.22 and $24.77 \%$, respectively) (Figure 4).

\section{Discussion}

In the present study, the use of cycles of alternate food restriction and refeeding in the matrinxã broodstock management during 6 months prior to spawning led to $35 \%$ of reduction in food consumption, but the food reduction did not alter severely the gonadal maturation of the females or their reproductive performance. Although fewer restricted females had spawned and produced fewer and smaller eggs, fertilization and hatchability

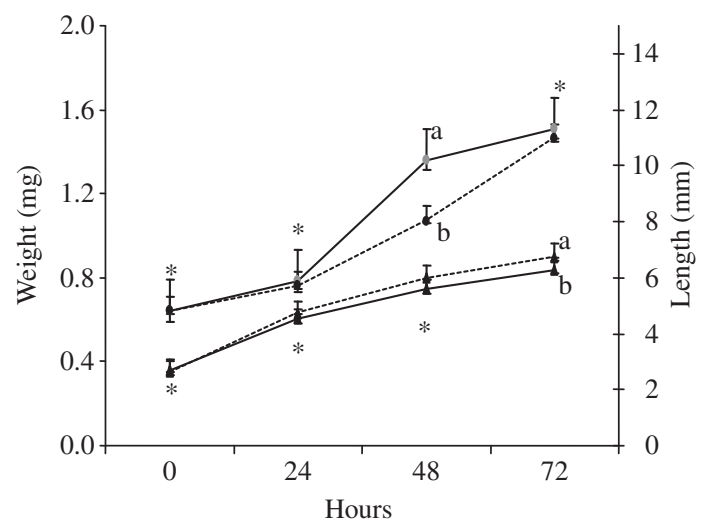

Figure 2. Weight (mg) and length (mm) of larvae produced by matrinxã females fed daily (G1) and by those fed 3 days/ unfed 2 days (G2) during 72 hours of incubation. Same letters indicate no significant differences between treatments. *Indicates same letters for all treatments in each time. Weight G1 (circle, continuous line), weight G2 (circle, dashed line), length G1 (triangle, continuous line), length G2 (triangle, dashed line).

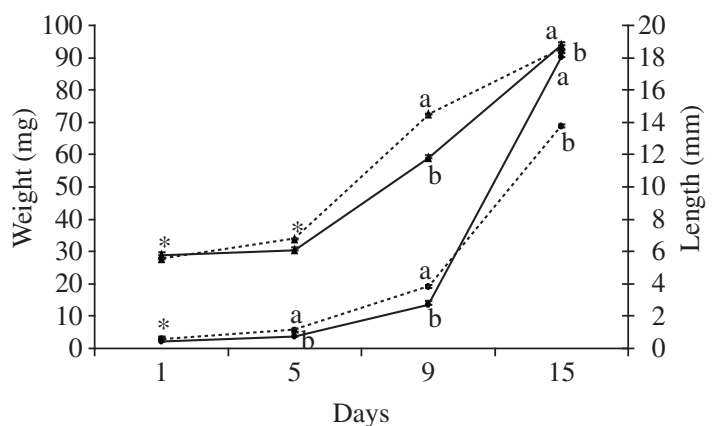

Figure 3. Weight (mg) and length (mm) of larvae produced by matrinxã females fed daily (G1) and by those fed 3 days/ unfed 2 days (G2) during the 15 days of rearing. Same letters indicate no significant differences between treatments. *Indicates same letters for all treatments in each time. Weight G1 (circle, continuous line), weight G2 (circle, dashed line), length G1 (triangle, continuous line), length G2 (triangle, dashed line). 


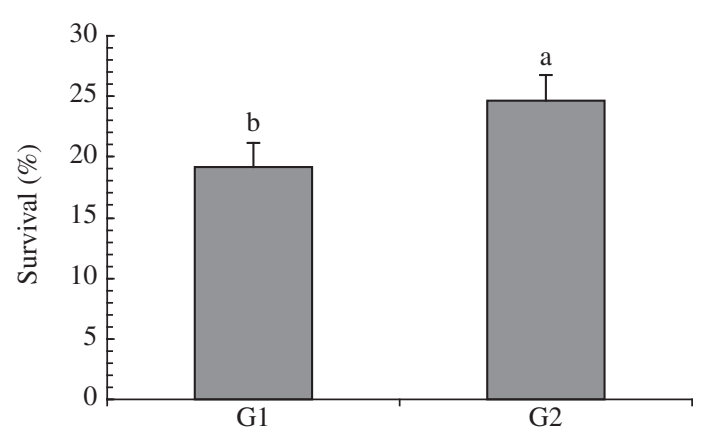

Figure 4. Survival (\%) of larvae produced by matrinxã females fed daily (G1) and by those fed 3 days/unfed 2 days (G2) at 15 days of rearing. Same letters indicate no significant differences between treatments

were not compromised. The higher growth and survival among larvae produced by food-restricted females indicated compensatory responses.

The effects of food restriction in reproductive fish performance are still controversial (Townshend and Wooton, 1984; Ridelman et al., 1984; Thorpe et al., 1990; Jobling et al. 1993; Reimers et al., 1993; Cerdá et al., 1994; Silverstein and Shimma, 1994; Karlsen et al., 1995; Toguyeni et al., 1996; Hopkins and Unwin 1997; Sohn et al., 1998; Collins and Anderson, 1999; Coward and Bromage, 1999; Duston and Saunders, 1999; Bromley et al., 2000; Carvalho, 2001) but the differences might come from the differences in the experimental design used in these studies (species, restriction and refeeding severity, season).

In several fish species, the better feeding conditions the better the reproductive performance of broodstock, gamete quality and fry production. Conversely reduced food supply can affect spawning success (Izquierdo et al., 2001). However, fish are regularly subjected to reduction in food supply during their life cycle including spawning migration (Mackenzie et al., 1998). The physiological decision to mature appears to be dependent on some measure of the rate of the storage of energy in fish. Shulman (1974), in an extensive review, found evidence to support the concept of a minimum fat content before maturation is initiated in a number of species. During food restriction, substantial somatic depletion occurs to support the body energy demand (Weatherley and Gill, 1987), which can affect the development of new tissues such as gonads. However, Coward and Bromage (1999) found that Tilapia zillii sacrificed somatic growth such that reproductive investment could be maintained. In matrinxã, oocyte quantity and size was found to be reduced in food-restricted females, although no effect was verified in fertilization and hatching rates. The causative effects of the determinants of egg quality are numerous and these are not only restricted to formulation or the ratio of the diets provided to broodstock, although these constitute the bases for the maternal influences of the quality of the progeny (Carrillo et al., 2000). According to Cerdá et al. (1994), feeding Dicentrarchus labrax broodstock at a half of their recommended daily ration of food during 6 months resulted in reduced estradiol plasma levels and reduced size of eggs and larvae. These authors affirm that reduction in oocyte size can occurs in several species due to low ration intake and inappropriate handling, but Ridelman (1984) reported that 40-day food restriction prior to spawning did not influence either egg viability or the egg's physical and chemical characteristics in rainbow trout, indicating that sufficient material was present in fish tissues to allow vitellogenesis to proceed to completion. Previously, Carvalho (2001) has demonstrated that feeding matrinxã broodstock with the same feeding strategy as this experiment ( 3 days full ratio/2 days no ratio) throughout the year did not reduce fish growth, lipid, carbohydrate and protein reserves, and gonadal development. Moreover, the same feeding strategy imposed on matrinxã broodstock during 3 months prior to spawning did affect negatively the number of spawned females, growth and survival of the fry (Camargo et al., 2003). The reduced number of spawned females verified in the restricted ratio group cannot be safely attributed to reduced food since individual differences of the fish response to artificial spawning is common (Kjorsvik et al., 2003). Additionally, gonadal maturation was apparently anticipated in matrinxã broodstock food restricted throughout the year (Carvalho, 2001).

In the study of Cerdá et al. (1994), despite clear reduction in size of the eggs and hatched fry of sea bass with restricted ration, there was a tendency to increase, in a compensatory way, the fecundity and number of spawning per fish in this group. It is not yet clear how food restriction can affect the growth and survival of the progeny but the present study showed promising results. Fry produced by food-restricted females were larger after 9 days of rearing which is a very interesting finding since larvae are recommended to be transferred from indoor facilities to outdoor tanks at that time. The bigger larvae are probably more able to face predators in tanks guaranteeing higher survival. Such results did not agree with Izquierdo et al. (2001), according to whom food restriction can alter gamete quality, and with Cerdá et al. (1994), who found that newly larvae from sea bass broodstock fed at a half food ration for 6 months were smaller. In addition to larger fry size, there was higher survival among larvae produced by matrinxã broodstock subjected to reduced food intake, although survival of larvae of food restricted sea bass was not affected in the study of Cerdá et al. (1994). This aspect is very important because poor quality eggs generally produced as a consequence of inadequate management may decrease the survival potential of the hatched larvae and this will affect directly the production success of any fish farm (Carrillo et al., 2000).

Several characteristics have been proposed to define the quality of the progeny (Kjorsvik et al., 2003; Lahnsteiner and Patarnello, 2004) including egg size (diameter of the eggs), fertilization rate, hatching rate 
and larval survival rate (Carrillo et al., 2000). Based on these characteristics, we might conclude that the feeding strategy imposed on matrinxã broodstock was not severe enough to affect their reproductive success as well as promoting a reduction in the costs of production.

Acknowledgements - The authors would like to thank Mrs. Damares Perecim Roviero for the technical assistance, Dr. Euclides Braga Malheiros for help with the statistical analyses, the Aquaculture Center of the University of Sao Paulo State (CAUNESP) for the facilities and the CEPTA/IBAMA (National Research Center of Tropical Fish) for fish donation.

\section{References}

BOYD, CE., 1979. Water quality in warm water fish ponds. Alabama Agricultural Experimental Station. New York: Auburn University. 359 p.

BROMLEY, JP., RAVIER, C. and WITHAMES, PR., 2000. The influence of feeding regime on sexual maturation, fecundity and atresia in first-time spawning turbot. J. Fish Biol., vol. 56, no. 2, p. 264-278.

CAMARGO, ACS., FERNANDES, JBK. and URBINATI, EC., 2003. Efeito da restrição alimentar moderada aplicada à fêmea de matrinxã (Brycon cephalus) no desempenho da progênie, p. 149-159. In: Anais do XII Simpósio Brasileiro de Aqüicultura, 2002, Goiânia.

CARRILLO, M., ZANUY, S., OYEN, F., CERDÁ, J., NAVAS, JM. and RAMOS, J., 2000. Some criteria of the quality of the progeny as indicators of physiological broodstock fitness. In Recent advances in Mediterranean aquaculture finfish species diversification. Zaragoza, 2000. vol. 47, p. 61-73. (Cahiers Options Méditerranéennes, Seminar of the CIHEAM Network on Technology of Aquaculture in the Mediterranean, 1999/05/24-28)

CARVALHO, EG. 2001. Restrição alimentar e reprodução em peixes. Jaboticabal: Centro de Aquicultura da UNESP. [PhD thesis].

CERDÁ, J., CARRILlO, M., ZANUY, S. and RAMOS, J., 1994. Effect of food ration on estrogen and vitellogenin plasma levels, fecundity and larval survival in captive sea bass, Dicentrarchus labrax: Preliminary observations. Aquat. Living Resources, vol. 7, p. 255-266.

COLLINS, AL. and ANDERSON, TA., 1999. The role of food availability in regulating reproductive development in female golden perch. J. Fish Biol., vol. 55, no.1, p. 94-104.

COWARD, K. and BROMAGE, NR., 1999. Spawning frequency, fecundity, egg size and ovarian histology in groups of Tilapia zillii maintained upon two distinct food ration sizes from first-feeding to sexual maturity. Aquat. Living Resources, vol. 12 , no. 1 , p. 11-22.

DUSTON, J. and SAUNDERS, RL., 1999. Effect of winter food deprivation on growth and sexual maturity of Atlantic salmon (Salmo salar) in seawater. Can. J. Fish. Aquat. Sci., vol. 56, no. 2, p. 201-207.
HOPKINS, CL. and UNWIN, MJ., 1997. The effect of restricted springtime feeding on growth and maturation of freshwaterreared chinook salmon, Oncorhynchus tshawytscha (Walbaum). Aquac. Res., vol. 28, no. 7, p. 545-549.

IZQUIERDO, MS., FERNÁNDEZ-PALACIOS, H. and TACON, AG., 2001. Effect of broodstock nutrition on reproductive performance of fish. Aquaculture, vol. 197, no. 1-4, p. 24-42.

JOBLING, M., JøRGENSEN, EH. and SIIKAVUPIO, SI. 1993. The influence of previous feeding regime on the compensatory growth response of maturing and immature Arctic charr, Salvelinus alpinus. J. Fish Biol., vol. 43, p. 409-419.

KARLSEN, Ø., HOLM, JC. and KJESBU, OS., 1995. Effects of periodic starvation on reproductive investment in firsttime spawning Atlantic cod (Gadus morhua L). Aquaculture, vol. 133 , no. 2 , p. 159-170.

KJORSVIK, E., HOEHNE-REITAN, K. and REITAN, KI. 2003. Egg and larval quality criteria as predictive measures for juvenile production in turbot (Scophthalmus maximus L.). Aquaculture, vol. 227, no. 1-4, p. 9-20.

LAHNSTEINER, F. and PATARNELLO, P., 2004. Egg quality determination in the gilt seabream, Sparus aurata, with biochemical parameters. Aquaculture, vol. 217, p. 443-459.

MACKENZIE, DS., VANPUTTE, CM. and LEINER, KA., 1998. Nutrient regulation of endocrine function in fish. Aquaculture, vol. 161, no. 1, p. 3-25.

REIMERS, E., KIØRREFJORD, AG. and STAVØSTRAND, SM., 1993. Compensatory growth and reduced maturation in second sea winter farmed Atlantic salmon following starvation in February and March. J. Fish Biol., vol. 43, no. 5, p. 805-810.

RIDELMAN, JM., HARDY, RW. and BRANNON, EL., 1984. The effect of short-term starvation on ovarian development and egg viability in rainbow trout (Salmo gairdneri). Aquaculture, vol. 37 , p. 133-140.

SILVERSTEIN, JT. and SHIMMA, H., 1994. Effect of restricted feeding on early maturation in female and male amago salmon, Oncorhynchus masou ishikawae. J. Fish Biol., vol. 45, p. 1133-1135.

SHULMAN, GE., 1974. Life cycles of fish. New York: John Wiley \& Sons. 423 p.

THORPE, JE., TALBOT, C., MILES, MS. and KEAY, DS., 1990. Control of maturation in culture Atlantic salmon, Salmo salar, in pumped seawater tanks, by restricting food intake. Aquaculture, vol. 86, p. 315-326.

TOGUYENI, A., BAROILLER, JF., FOSTIER, A., LE BAIL, PY., KÜHN, ER., MOL, KA. and FAUCONNEU, B., 1996. Consequences of food restriction on short-term growth variation and plasma circulating hormones in Oreochromis niloticus in relation to sex. Gen. Comp. Endocrinol., vol. 103, no. 2, p. $167-175$.

TOWNSHEND, TJ. and WOOTTON, RJ., 1984. Effects of food supply on the reproduction of the convict cichlid, Cichlasoma nigrofasciatum. J. Fish Biol., vol. 24, no. 1, p. 91-104.

WEATHERLEY, AH. and GILL, HS., 1987. The Biology of Fish Growth. London: Academic Press. 443 p. 